\title{
BADANIE SATYSFAKCJI STUDENTÓW Z SYSTEMU ANKIETYZACJI
}

\begin{abstract}
Dbałość o wysoką jakość procesu kształcenia jest cechą charakterystyczną każdej szanującej się uczelni wyższej. Cel taki, jako najstarszej i największej uczelni technicznej w południowo-wschodniej Polsce, przyświeca również Politechnice Rzeszowskiej im. Ignacego Łukasiewicza. Właściwe dobrani nauczyciele akademiccy, właściwe programy kształcenia i inne zasoby zwiększają prawdopodobieństwo osiągania przez studentów założonych efektów kształcenia. Te z kolei zwiększają szansę absolwentów na satysfakcjonującą pracę i karierę zawodową. Żeby działania uczelni w zakresie kształcenia spełniały tę rolę należy je doskonalić, aby odpowiadały wciąż zmieniającemu się otoczeniu. Aby ustalić kierunki doskonalenia należy wykorzystywać znane narzędzia oceny. Jednym z takich narzędzi jest ankieta. Stosowany w Politechnice Rzeszowskiej system zapewniania jakości kształcenia wymusza prowadzenie ankiet. Są to ankiety: nauczyciela akademickiego, modułu kształcenia, oceny modułu kształcenia, organizacji studiów, pracodawcy i pracownika niebędącego nauczycielem akademickim. Wszystkie ankiety są prowadzone w systemie USOS $\mathrm{z}$ wyjątkiem prowadzonej przy pomocy pilotów ankiety nauczyciela akademickiego. Ankiety są anonimowe, a wyniki po prezentacji władzom wydziałów i uczelni służyć mają doskonaleniu kształcenia. Prowadzona w ten sposób ankieta powinna jednak też podlegać doskonaleniu. Sam przegląd kończy się najczęściej alternatywą oceną podsumowującą. Dlatego celowe wydało się przeprowadzenie badania satysfakcji studentów ze stosowanego systemu ankietyzacji obowiązującego w Politechnice Rzeszowskiej. Badania takie przy pomocy Samorządu Studenckiego Politechniki Rzeszowskiej przeprowadzono w 2016 roku. W opracowaniu zaprezentowano wyniki tego badania.
\end{abstract}

Słowa kluczowe: jakość kształcenia, ankietyzacja, satysfakcja studentów

\section{WSTĘP}

Proces kształcenia w uczelniach wyższych jest weryfikowany poprzez pracowników uczelni, komisje akredytujące, a także poprzez wprowadzone elementy Deklaracji Boloń-

${ }^{1}$ Prof. dr hab. Grzegorz Ostasz, Katedra Nauk Humanistycznych, Wydział Zarządzania, Politechnika Rzeszowska, ul. Podkarpacka 1, 35-082 Rzeszów, e-mail: gost@prz.edu.pl

${ }^{2}$ Mgr inż. Joanna Woźniak (autor korespondencyjny), Katedra Systemów Zarządzania i Logistyki, Wydział Zarządzania, Politechnika Rzeszowska, al. Powstańców Warszawy 8, 35-959 Rzeszów, e-mail: j.wozniak@prz.edu.pl

${ }^{3}$ Dr hab. inż. Andrzej Pacana, Katedra Technologii Maszyn i Inżynierii Produkcji, Wydział Budowy Maszyn i Lotnictwa, Politechnika Rzeszowska, al. Powstańców Warszawy 8, 35-959 Rzeszów,e-mail: app@prz.edu.pl 
skiej, wdrożone systemy zarządzania jakością ISO 9001, IWA2, CAF, czy Krajowe Ramy Kwalifikacji. Wprowadzenie Krajowych Ram Kwalifikacji do szkolnictwa wyższego w Polsce wydaje się być bardzo korzystne dla naszego kraju. Należy mieć na uwadze fakt, że żadne zalecenia czy ustalenia na poziomie europejskim, związane z Procesem Bolońskim, czy decyzjami organów Unii Europejskiej nie obowiązują żadnego państwa pozaeuropejskiego.

Najczęściej podaje się trzy główne powody, dla których kraje Unii Europejskiej oraz znaczna liczba krajów spoza Unii Europejskiej zdecydowały się oprzeć jakość swojego szkolnictwa wyższego na krajowych ramach kwalifikacji:

1) Pierwszym z tych powodów jest rosnąca mobilność obywateli UE. Dotyczy to zarówno mobilności studentów, ale także i mobilność absolwentów uczelni i szkół innych typów na europejskim rynku pracy.

2) Drugim, istotnym powodem stosowania ram kwalifikacji jest coraz wyraźniej rysująca się potrzeba uwzględnienia perspektywy uczenia się przez całe życie. Ciągłe kształcenie powodować będzie konieczność wielokrotnego powrotu wielu osób (absolwentów) do systemu edukacji, w celu poszerzenia (ewentualnie wzbogacenia) swoich kwalifikacji.

3) Trzecim ważnym powodem jest umasowienie w Polsce kształcenia na poziomie wyższym - w ostatnich latach liczba studentów wzrosła niemal pięciokrotnie; obecnie więcej, niż co drugi młody człowiek w wieku 19-24 lat studiuje. Jest to zmiana znacząca, zważywszy, że jeszcze niedawno studiowało zaledwie około $10 \%$ najzdolniejszych młodych ludzi z każdego rocznika. Zjawisko to, niezwykle pochlebnie komentowane w świecie, ma swoje istotne konsekwencje dla procesu kształcenia i jego rezultatów. Realizacja procesu kształcenia w poprzedniej formule - tak, jakby się nic nie zmieniło, nie doprowadzi do oczekiwanych wyników ${ }^{4}$.

Istotne są w tym działaniu dwa występujące łącznie elementy: programy kształcenia i efekty kształcenia. Program kształcenia to opis określonych przez uczelnię spójnych efektów kształcenia, zgodny z Krajowymi Ramami Kwalifikacji dla Szkolnictwa Wyższego, oraz opis procesu kształcenia, prowadzącego do osiągnięcia tych efektów, wraz z przypisanymi do poszczególnych modułów tego procesu punktami ECTS. Wspomniane w definicji programów kształcenia efekty kształcenia rozumiane jako zasób wiedzy, umiejętności i kompetencji społecznych uzyskanych w procesie kształcenia przez osobę uczącą się powinny być traktowane jako nadrzędne wobec programu studiów. Program studiów, obejmujący m.in. plan studiów i opis poszczególnych modułów kształcenia, powinien być tworzony w oparciu o uprzednio zdefiniowane efekty kształcenia. Działania na rzecz jakości kształcenia są niezwykle istotne, z punktu widzenia prowadzonych procesów dydaktycznych, które nieco inaczej wyglądają na studiach stacjonarnych, niestacjonarnych, doktoranckich czy podyplomowych. Aby ewentualnym problemom związanym z jakością kształcenia stawić czoło trzeba obiektywnie ocenić aktualny sposób realizacji programów kształcenia ${ }^{5}$. Stąd jednym z zadań jednostki prowadzącej studia jest stosowa-

\footnotetext{
${ }^{4}$ A. Kraśniewski, Projekt Ministerstwa Nauki i Szkolnictwa Wyższego „Krajowe Ramy Kwalifikacji w szkolnictwie wyższym jako narzędzie poprawy jakości ksztatcenia” www.procesbolonski. uw.edu.pl/.../publikacja_MNISW_AK_111103.pdf

5 A. Pacana, G. Ostasz, Narzędzia zarządzania jakościa w analizie i ocenie jakości kształcenia [w:] Dydaktyka zawodowa. Dylematy $i$ wyzwania, red. R. Stawicki, Legionów 2015, s. 146-157; A. Pacana, J. Sęp, W. Zielecki, Ocena jakości ustug dydaktycznych na przyktadzie studiów
} 
nie odpowiednich mechanizmów (procedur) oceny. Ocenę taką można wykonać w różny sposób. Częstym przypadkiem jest np. ankietyzacja. Odbywa się ona zwyczajowo po zakończonym semestrze roku akademickiego. Celem opracowania jest analiza wyników ankietyzacji w Politechnice Rzeszowskiej. Badanie zostało przeprowadzone w 2016 roku na grupie 1166 studentów 6 .

\section{ANKIETYZACJA W POLITECHNICE RZESZOWSKIEJ}

Politechnika Rzeszowska im. Ignacego Łukasiewicza to najstarsza i największa uczelnia techniczna w południowo-wschodniej Polsce. Od 1976 roku Politechnika Rzeszowska - jako jedyna uczelnia w kraju - prowadzi kształcenie pilotów lotnictwa cywilnego. W 2016 roku uzyskała status uniwersytetu technicznego. Politechnika kształci około 16,5 tys. studentów na siedmiu wydziałach. Są to:

- Wydział Budownictwa, Inżynierii Środowiska i Architektury (RB),

- Wydział Budowy Maszyn i Lotnictwa (RM),

- Wydział Chemiczny (RC),

- Wydział Elektrotechniki i Informatyki (RE),

- Wydział Matematyki i Fizyki Stosowanej (RF),

- Wydział Mechaniczno-Technologiczny (RS),

- Wydział Zarządzania (RZ).

Od 2013 roku w uczelni funkcjonuje sformalizowany system zapewniania jakości kształcenia. Jednym z zadań wewnętrznego systemu zapewniania jakości kształcenia realizowanym na Uczelni jest rozwijanie kultury ewaluacyjnej w środowisku akademickim poprzez poddawanie ocenie jakości dydaktyki. Istotna w ewaluacji procesu kształcenia jest kwestia poufności w trakcie zbierania danych i publikowania informacji. Dlatego na Politechnice Rzeszowskiej narzędziem wykorzystywanym do oceny jakości zajęć dydaktycznych oraz do oceny prowadzących zajęcia nauczycieli akademickich są anonimowe ankiety. Aktualny sposób ankietyzacji obejmuje badania skierowane do interesariuszy wewnętrznych (studentów, doktorantów, słuchaczy studiów podyplomowych) jak również interesariuszy zewnętrznych (pracodawców). Przedmiotem badań są m.in. opinie wyrażane na temat prowadzonych zajęć dydaktycznych, satysfakcji ze studiowania, dostosowania programów kształcenia do potrzeb rynku pracy, opinie pracodawców na temat ich oczekiwań wobec absolwentów Uczelni. W procesie ankietyzacji aktualnie stosuje się:

- Ankietę nauczyciela akademickiego,

- Ankietę modułu kształcenia,

- Ankietę oceny modułu kształcenia,

- Ankietę organizacji studiów,

podyplomowych. Komputerowo zintegrowane zarzadzanie, Opole 2011; A. Pacana, Koncepcja ankietowego badania jakości procesów dydaktycznych. Recenzovaný zborník vedeckých prác $\mathrm{k}$ riešeniu projektov MVP č. 23320262, 2330263, 2330264, „PERFECT (PERFormance \& EffiCiencyIndicaTors)“ „Uplatnenie inovatívnych metód vo výučbe manažérskych a ekonomických disciplín II.”,Európska únia na ceste k ciel’u stratégie Európa 2020“, Košicie 2012, s. 72-80.

${ }^{6}$ B. Zatwarnicka-Madura, Wybrane aspekty promocji szkót wyższych na przykładzie Politechniki Rzeszowskiej [w:] Projektowanie i wdrażanie strategii rozwoju w Publicznych Szkołach Wyższych $w$ Polsce - aspekty teoretyczne i praktyczne, Zeszyty Naukowe nr 167, red. Sz. Cyfert i C. Kochalski, Poznań 2011. 
- Ankietę pracodawcy,

- Ankietę pracownika niebędącego nauczycielem akademickim.

$\mathrm{Na}$ wykresie 1 została zaprezentowano w ujęciu procentowym liczbę ankiet wypełnionych przez studentów poszczególnych wydziałów Uczelni:

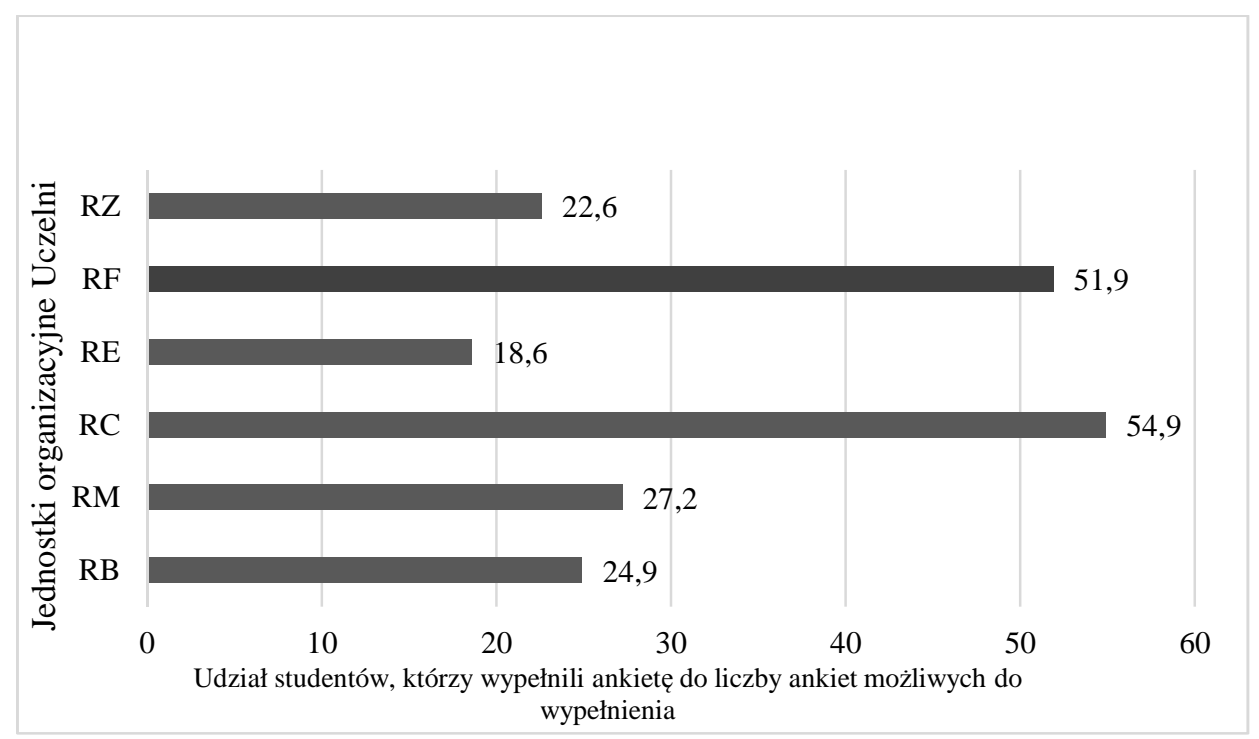

Wykres 1. Aktywność studentów w ramach akcji projakościowej „Głosujesz - PRzyszłość budujesz" w semestrze zimowym w roku akademickim 2015/2016.

W przypadku ankiet oceniających nauczyciela akademickiego ankietyzacja prowadzona była przy użyciu elektronicznego systemu zbierania odpowiedzi z wykorzystaniem pilotów, a w pozostałych ankietach wykorzystano system USOS.

\section{METODYKA BADANIA}

Systematyczna dokonywana ocena zajęć przez interesariuszy wewnętrznych odzwierciedla bieżącą ich satysfakcję co ma duży wpływ na przyszłość na Uczelni. Dlatego uznano za celowe, aby wraz z Samorządem Studenckim ocenić na ile prowadzony sposób ankietyzacji spełnia oczekiwania studentów.

Badanie satysfakcji studentów z systemu ankietyzacji obowiązującego w Politechnice Rzeszowskiej zostało przeprowadzone w dniach 1-19 lutego 2016 roku.

Jako narzędzie badawcze wykorzystano kwestionariusz ankietowy, który został udostępniony w formie elektronicznej za pomocą formularza Google. Ankieta została opublikowana pod hasłem - Teraz to TY możesz wystawić ocenę! - ankietyzacja PRz.

Kwestionariusz został opublikowany na stronie internetowej Samorządu Studenckiego Politechniki Rzeszowskiej. Informacja o badaniu została umieszczona również na oficjalnej stronie internetowej Politechniki Rzeszowskiej oraz w Systemie USOS-web Politechniki Rzeszowskiej. 
Formularz składał się z trzech pytań zamkniętych:

1) Czy uważasz, że ankietyzacja prowadzona na Uczelni ma wpływ na podnoszenie jakości kształcenia?

2) Jak oceniasz organizację przebiegu procesu ankietyzacji na Uczelni?

3) Czy uważasz, że aktualnie obowiązujące pule pytań ankiet stosowanych na Uczelni powinny zostać uzupełnione o dodatkowe pytanie w przyszłym roku akademickim?

W celu efektywniejszej interpretacji pytania $3 \mathrm{w}$ kwestionariuszu dodano pytanie otwarte, które miało na celu precyzyjne określenie przez respondentów zagadnienia jakie powinno pojawić się podczas ankietyzacji w przyszłych semestrach. Zamieszczona w kwestionariuszu metryczka dodatkowo wzbogaciła badanie o dane dotyczące Wydziału oraz roku studiów na jakim znajdują się studenci.

\section{WYNIKI BADAŃ}

\subsection{Charakterystyka respondentów}

W ciagu dziewiętnastu dni ankietę wypełniło łącznie 1166 studentów.

Jak przedstawiono na wykresie 2 największą liczbę respondentów stanowili studenci Wydziału Zarządzania w liczbie 448 osób (38,4\%), a następnie kolejno: Wydziału Budowy Maszyn i Lotnictwa (21,4\%), Wydziału Chemicznego (12,7\%), Wydziału Matematyki

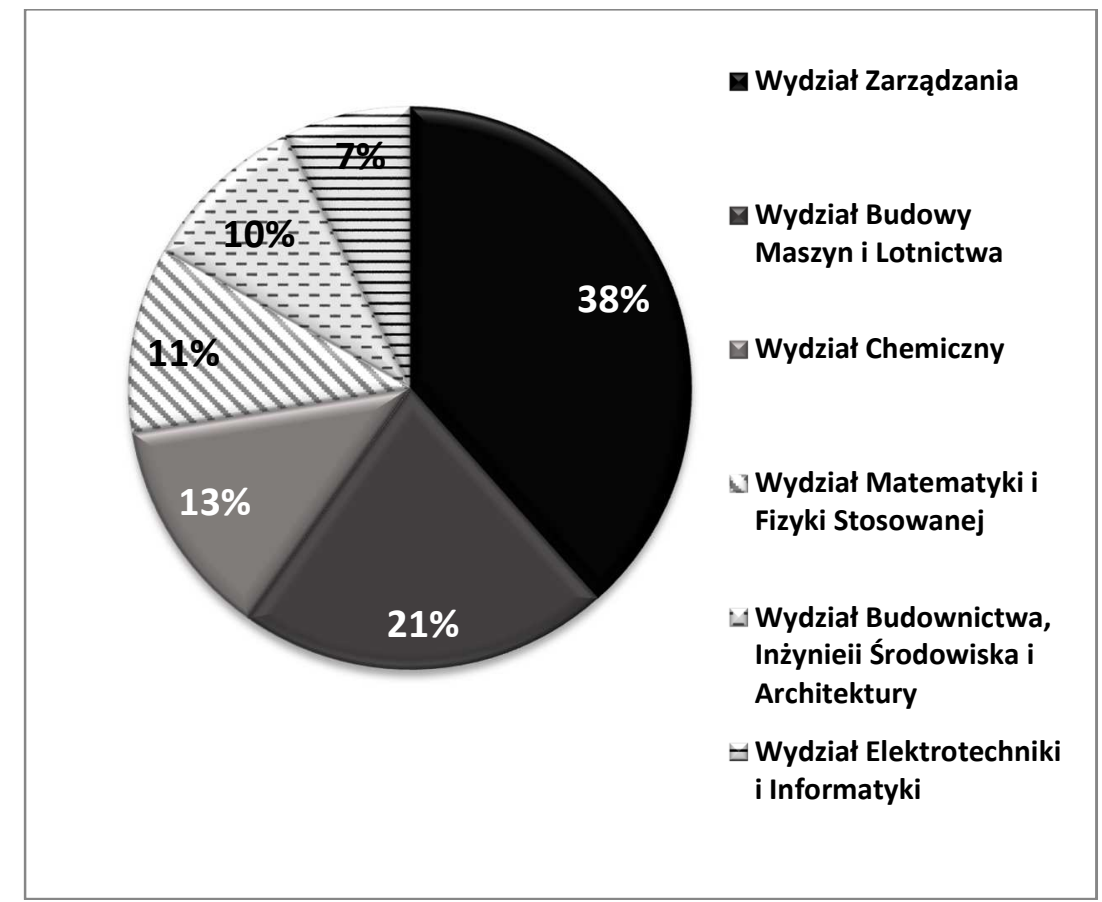

Wykres. 2. Udział procentowy studentów w ankiecie według przynależności do Wydziału 
i Fizyki Stosowanej (10,6\%) oraz Wydziału Budownictwa, Inżynierii Środowiska i Architektury $(9,6 \%)$. Z oczywistych względów w badaniu nie brali udziału studenci najmłodszego Wydziału Mechaniczno-Technologicznego, który został utworzony 15 grudnia 2016 roku. Najmniejsza liczba respondentów to studenci Wydziału Elektrotechniki i Informatyki w liczbie 85 osób (7,3\%).

Kolejne pytanie w metryczce dotyczyło roku studiów na jakim znajdują się respondenci. Jak przedstawiono na wykresie 3 badanie przeprowadzono w zróżnicowanej grupie, w której większość stanowią studenci pierwszego roku w liczbie 367 osób (31\%) oraz drugiego roku w liczbie 291 osób (25\%). Z kolei $19 \%$ ankietowanych to studenci trzeciego roku, a $13 \%$ - czwartego roku studiów. Najmniejsza liczba respondentów to studenci piątego roku - 136 osób (12\%).

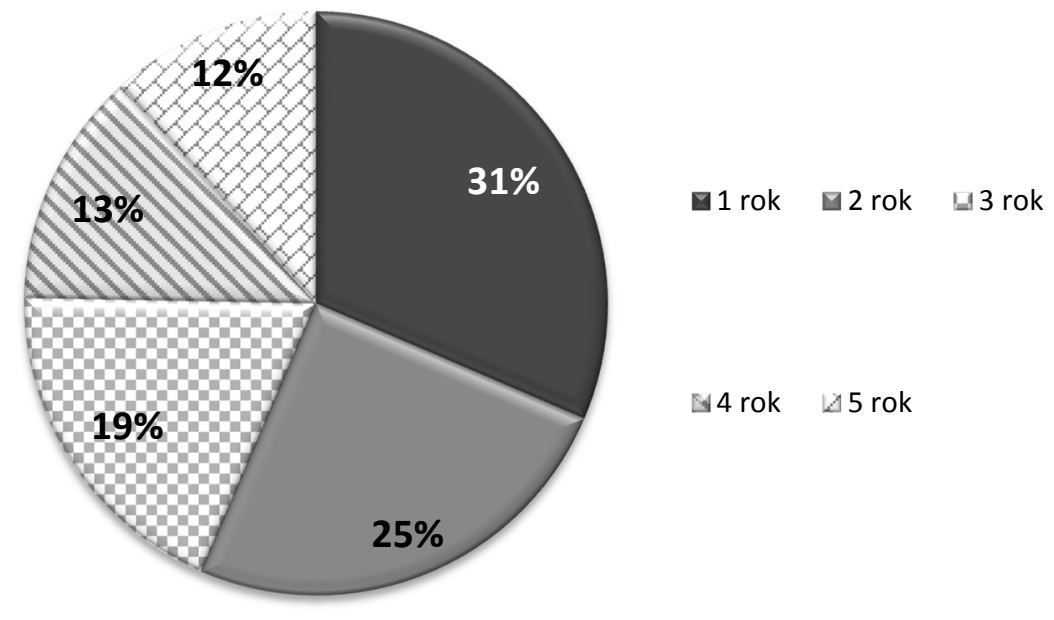

Wykres 3. Udział procentowy studentów w ankiecie według roku studiów

\subsection{Ankietyzacja a jakość kształcenia}

Pierwsze pytanie w ankiecie dotyczyło oceny przez studentów wpływu ankietyzacji na podnoszenie jakości kształcenia na Uczelni (wykres 4). Badania wskazują, że większość ankietowanych (42\%) stwierdziło, iż przeprowadzanie ankietyzacji w pewnym stopniu wpływa na podnoszenie jakości kształcenia. $27 \%$ respondentów stwierdziło, że ankietyzacja ma wpływ na podnoszenie jakości, $21 \%$ studentów oświadczyło, że ankietyzacja nie ma znaczenia. Z kolei $10 \%$ ankietowanych nie sprecyzowało swojej opinii w tej kwestii. Z wyników wynika, że wg respondentów prowadzenie ankietyzacji może przyczynić się do podniesienia jakości kształcenia, nie jest to jednak opinia powszechna.

Wykres 5 przedstawia opinię respondentów na temat organizacji procesu ankietyzacji na Uczelni. Pytanie zostało skonstruowane w oparciu o pięciostopniową skalę typu Likerta, gdzie cyfra 1 oznaczała ocenę bardzo złą, natomiast cyfra 5 - bardzo dobrą. 


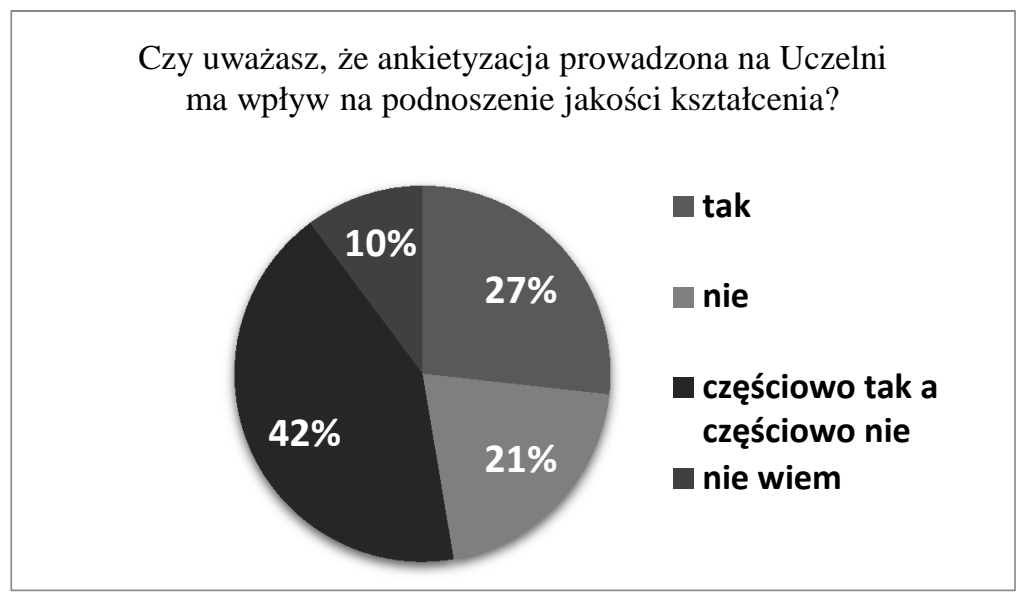

Wykres 4. Opinia respondentów dotycząca wpływu przeprowadzania ankietyzacji na podnoszenie jakości kształcenia

Dane zawarte na wykresie 5 skłaniają do stwierdzenia, że większość respondentów ocenia przebieg procesu ankietyzacji na poziomie dobrym $(45 \%)$. Średnia ocen w tym przypadku jest równa 3,82. Zaledwie siedemnastu respondentów (1\%) uznaje, że organizacja procesu ankietyzacji jest bardzo zła.

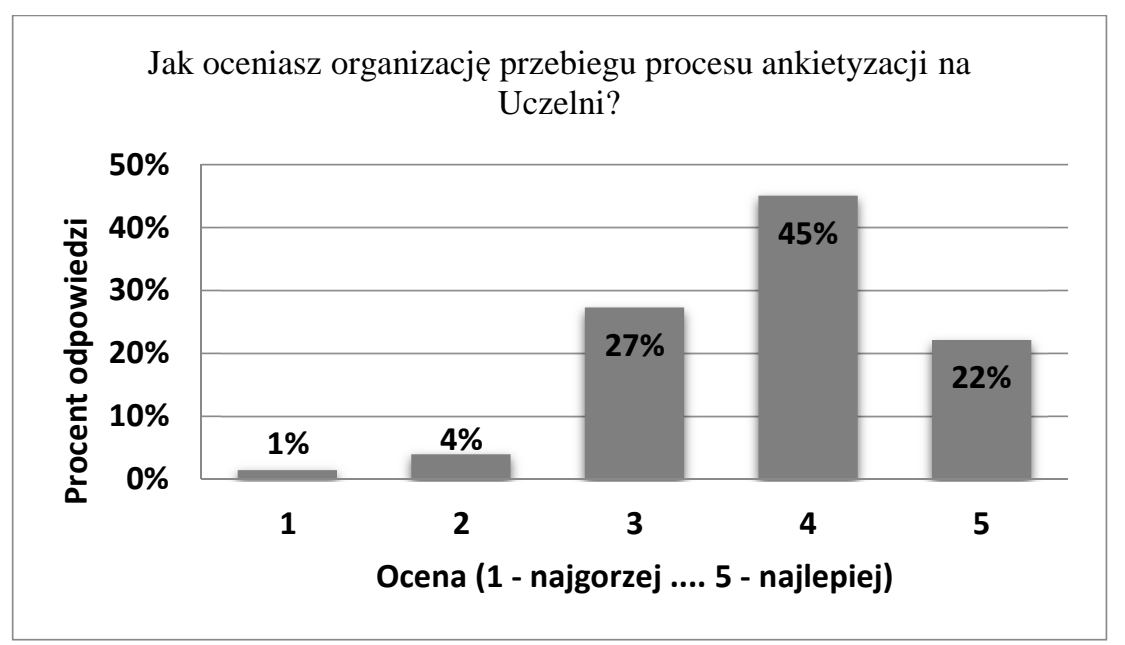

Wykres 5. Opinia respondentów dotycząca organizacji przebiegu procesu ankietyzacji na Uczelni

Kolejne pytanie w ankiecie dotyczyło puli pytań w ankiecie stosowanych na Uczelni. $77 \%$ ankietowanych (899 osób) oceniło ankietę jako kompletną. 23\% respondentów (267 osób) wyraziło opinię, iż pula pytań powinna zostać uzupełniona o dodatkowe treści. Graficzne przedstawienie wyników przedstawia wykres 6. 


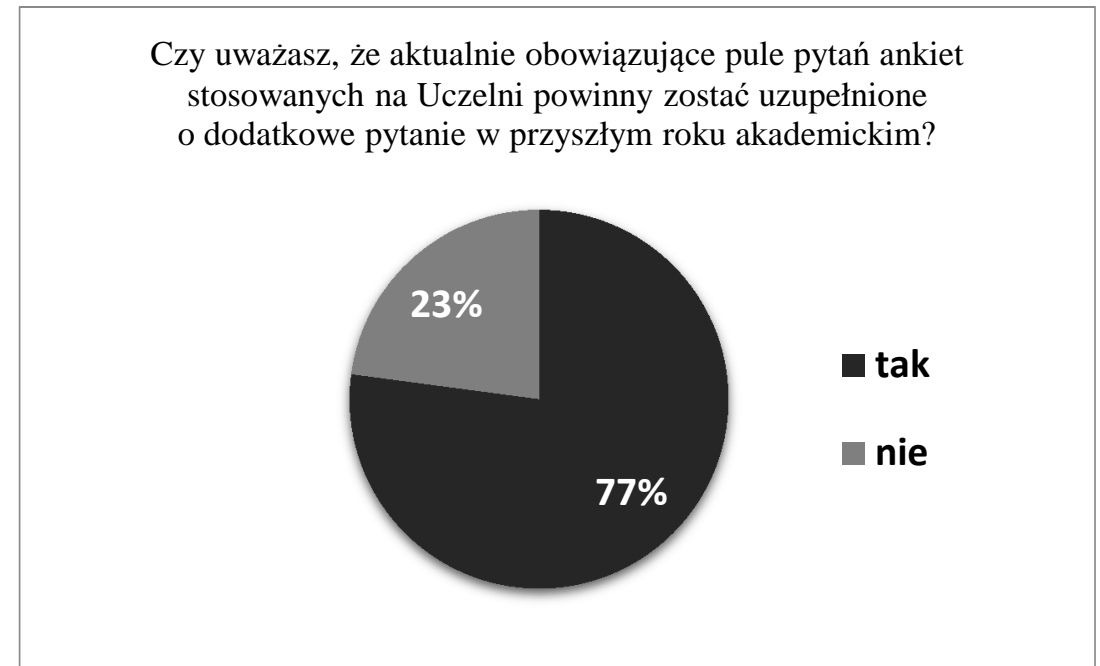

Wykres 6. Opinia respondentów dotycząca puli pytań stosowanych w ankiecie

Pytanie 4, dotyczące precyzyjnego określenia przez studentów kwestii jakie powinny pojawić się w przyszłych ankietach, zostało skategoryzowane według podobnych odpowiedzi. Wśród nich pojawiły się następujące zagadnienia (w nawiasach podano liczbę podobnych komentarzy):

- stosunek prowadzącego do studenta (35),

- sposób prowadzenia zajęć (przygotowanie i zaangażowanie prowadzącego) (21),

- sprawiedliwość oceniania (10),

- przykłady zastosowani teorii w praktyce (6),

- wywiązywanie się z obowiązków przez prowadzących (5),

- dostępność prowadzącego podczas konsultacji (4),

- praktyczność przedmiotu (4),

- terminowość poprawiania kolokwiów/egzaminów (2),

- punktualność prowadzącego (1),

- liczba odwołanych zajęć (1).

Udzielający odpowiedzi studenci, zdecydowanie opowiedzieli się za koniecznością ankietowania w przyszłości stosunku prowadzącego do studenta i sposobu prowadzenia zajęć. Informacje takie należałoby uwzględnić w przyszłych ankietach. Być może wpłynie to na wzrost liczby wypełnionych ankiet.

\section{PODSUMOWANIE}

Świadczenie wysokiej jakości usług edukacyjnych przez szkoły wyższe nabiera coraz większego znaczenia ${ }^{7}$. Procesy dydaktyczne, podobnie jak każde inne procesy, powinny

${ }^{7}$ M. Ozgol, I. Sarikaya, M. Ozturk, Students' and Teaching Staff's Assessments Regarding Distance Education Applications in Formal Education, „Yükseköğretim ve Bilim Dergisi/ Journal of Higher Education and Science" 2017, 7(2); K. Putica, D. Trivić, Improving high-school students' 
być więc poprawnie identyfikowane i doskonalone ${ }^{8}$. Uczelnie wyższe chcąc sprostać wymaganiom rynkowym powinny wprowadzać działania doskonalące, jak najbardziej zbliżone do oczekiwań studentów. Właściwe rozpoznanie potrzeb może być oparte np. na badaniu ankietowym, które pozwoli otrzymać odpowiednie informacje i dane o tym, które obszary wymagają zmiany lub poprawy. Do takiej sfery należy również sam proces ankietyzacji, który również powinien ewaluować, aby stać się jak najbardziej przystępny dla respondentów oraz miarodajny dla badaczy.

Władze Politechniki Rzeszowskiej przy współpracy z Samorządem Studenckim postanowiły przeprowadzić badania satysfakcji studentów z systemu ankietyzacji. Przeprowadzenie opisanego badania pozwoliło na sformułowanie następujących wniosków:

- większość ankietowanych stwierdziła, że przeprowadzanie ankietyzacji w pewnym stopniu wpływa na podnoszenie jakości kształcenia,

- ogólna średnia ocena procesu ankietyzacji przeprowadzonego na Uczelni została określona na poziomie dobrym,

- większość respondentów ocenia ankietę jako kompletną.

Reasumując, można stwierdzić, że badanie satysfakcji studentów z systemu ankietyzacji przeprowadzanego na Politechnice Rzeszowskiej pozwoliło na rozpoznanie opinii studentów na temat procesu ankietowania. Badanie to nadało również władzom Uczelni pewne wskazówki co do kierunku rozwoju oraz wprowadzenia działań doskonalących procesu ankietyzacji. Spośród najliczniejszych odpowiedzi nt. zagadnień, o jakie powinny zostać - według opinii studentów - wzbogacone pytania ankietowe obowiązujące od roku akademickiego 2016/2017 wymieniono: stosunek prowadzącego do studenta, sposób prowadzenia zajęć (przygotowanie i zaangażowanie prowadzącego), sprawiedliwość oceniania, przykłady zastosowania teorii w praktyce, wywiązywanie się z obowiązków przez prowadzących, dostępność prowadzącego podczas konsultacji, praktyczność przedmiotu, terminowość poprawiania kolokwiów/egzaminów, punktualność prowadzącego, a także liczbę odwołanych zajęć.

\section{Literatura}

[1] Kraśniewski A., Projekt Ministerstwa Nauki i Szkolnictwa Wyższego „Krajowe Ramy Kwalifikacji w szkolnictwie wyższym jako narzędzie poprawy jakości ksztatcenia”, www.procesbolonski.uw.edu.pl/.../publikacja_MNISW_AK_111103.pdf.

[2] Maciąg J., Wzorzec jakości ustugi edukacyjnej, „Problemy Jakości” 2005, nr 2.

[3] Ozgol M., Sarikaya I., Ozturk M., Students' and Teaching Staff's Assessments Regarding Distance Education Applications in Formal Education, ,,Yükseköğretim ve Bilim Dergisi/ Journal of Higher Education and Science" 2017, 7(2).

conceptual understanding and functionalization of knowledge about digestion through the application of the interdisciplinary teaching approach, „Journal of Baltic Science Education” 2017, 16(1).

8 J. Maciąg, Wzorzec jakości ustugi edukacyjnej, „Problemy Jakości” 2005, nr 2; R. Wolniak, The assessment of significance of benefits gained from the improvement of quality management systems in Polish organizations, „Quality \& Quantity” 2013, 41(1); D. Zimon, Impact of the implementation of quality management system on operating cost for small and medium-sized business organizations affiliated to a purchasing group, "International Journal for Quality Research" 2015, 9(4). 
[4] Pacana A., Ostasz G., Narzędzia zarządzania jakościq w analizie i ocenie jakości ksztatcenia [w:] Dydaktyka zawodowa. Dylematy $i$ wyzwania, red. R. Stawicki, Wydział Wydawnictw i Poligrafii Centrum Szkolenia Policji w Legionowie, Legionów 2015.

[5] Pacana A., Sęp J., Zielecki W., Ocena jakości usług dydaktycznych na przykładzie studiów podyplomowych. Komputerowo zintegrowane zarzadzanie, Oficyna Wydawnicza Polskiego Towarzystwa Zarządzania Produkcją, Opole 2011.

[6] Pacana A., Koncepcja ankietowego badania jakości procesów dydaktycznych. Recenzovaný zborník vedeckých prác k riešeniu projektov MVP č. 23320262, 2330263, 2330264, „PERFECT (PERFormance \& EffiCiencyIndicaTors)“ „Uplatnenie inovatívnych metód vo výučbe manažérskych a ekonomických disciplín II.”„Európska únia na ceste k ciel’u stratégie Európa 2020“ Ekonomická univerzita v Bratislave, Podnikovohospodárska fakulta v Košiciach, Košicie 2012.

[7] Putica K., Trivić D., Improving high-school students' conceptual understanding and functionalization of knowledge about digestion through the application of the interdisciplinary teaching approach, „Journal of Baltic Science Education” 2017, 16(1).

[8] Wolniak R., The assessment of significance of benefits gained from the improvement of quality management systems in Polish organizations, „Quality \& Quantity” 2013, 41(1).

[9] Zatwarnicka-Madura B., Wybrane aspekty promocji szkót wyższych na przyktadzie Politechniki Rzeszowskiej [w:] Projektowanie $i$ wdrażanie strategii rozwoju w Publicznych Szkołach Wyższych w Polsce - aspekty teoretyczne i praktyczne, Zeszyty Naukowe, nr 167, red. Sz. Cyfert i C. Kochalski, Wyd. UE w Poznaniu, Poznań 2011.

[10] Zimon D., Impact of the implementation of quality management system on operating cost for small and medium-sized business organizations affiliated to a purchasing group, "International Journal for Quality Research" 2015, 9(4).

\section{RESEARCH ON STUDENTS' SATISFACTION WITH THE QUESTIONNAIRE} SYSTEM

The attention to the high quality of the learning process is the hallmark of every selfrespecting university. This is also an objective of one of the oldest and largest technical university in south-eastern Poland - Ignacy Łukasiewicz Rzeszow University of Technology. Properly selected academics, relevant training programs and other resources to increase the likelihood of achieving the learning outcomes of students assumed. These, in turn, increase the chances of graduates to get satisfying work and career. University activities need to be improved to fulfill the requirements of constantly changing environment. To determine the directions of improvement one should use familiar tools of evaluation. One of such a tool is the survey. Quality assurance system applied at the Rzeszow University of Technology forces conducting surveys. They are the subject of a teacher training module, evaluation module of training, organization of studies, the employer and the worker who is not an academic teacher. All the surveys are carried out in the system USOS except those conducted with the pilot survey of academic teacher. The surveys are anonymous and the results after the presentation of faculty and university authorities serve to improve education. However, conducted a survey in this way should be also improved. The review itself concludes on the most common alternative assessment 
summary. Therefore, it would be advisable to release a survey on student satisfaction with the system in force at the Rzeszow University of Technology. Such a survey with the support from the Student Government of the Rzeszow University of Technology was conducted in 2016. The paper presents the results of this study.

Keywords: quality of education, the questionnaire, satisfaction of students.

DOI: $10.7862 / \mathrm{rz} .2017 . \mathrm{mmr} .44$

Tekst złożono $w$ redakcji: październik 2017 r.

Przyjęto do druku: styczeń 2018 r. 
